\title{
Detection of viruses and virus-like particles in four species of wild and farmed bivalve molluscs in Alaska, USA, from 1987 to 2009
}

\author{
Theodore R. Meyers ${ }^{1, *}$, Tamara Burton ${ }^{2}$, Wally Evans ${ }^{2}$, Norman Starkey ${ }^{2}$ \\ ${ }^{1}$ Department of Fish and Game, Commercial Fisheries Division, Juneau Fish Pathology Laboratory, PO Box 115526, \\ Juneau, Alaska 99811-5526, USA \\ ${ }^{2}$ Alaska Department of Fish and Game, Commercial Fisheries Division, Anchorage Fish Pathology Laboratory, \\ 333 Raspberry Road, Anchorage, Alaska 99518, USA
}

\begin{abstract}
The US Alaska Department of Fish and Game has regulatory oversight of the mariculture industry that is partially administered through a statewide shellfish health policy. Possession and transport of bivalve molluscs require development of indigenous pathogen histories from diagnostic examinations of wild and farmed populations. These examinations have resulted in the detection of various infectious agents and parasites including viruses: an aquareovirus and aquabirna-like virus isolated by fish cell culture, and papilloma- or polyoma- and herpes-like virus particles within bivalve cell intranuclear inclusion bodies observed by electron microscopy. This study summarizes these results in samples examined from 1987 to 2009 and is the first description of poikilothermic viruses from Alaskan waters isolated from or observed within the tissues of 4 species of bivalve molluscs: geoduck clam Panope abrupta, native littleneck clam Protothaca staminea, purple-hinged rock scallop Crassadoma gigantea and Pacific oyster Crassostrea gigas.
\end{abstract}

KEY WORDS: Viruses · Alaska · Bivalves

\section{INTRODUCTION}

The Alaska Department of Fish and Game (ADFG) exercises stringent aquatic animal health policies for both finfish and shellfish that were initiated in a single document in 1988, henceforth referenced as 'the policy' (Meyers 2003). The policy requires permits to possess and transport aquatic animals for aquaculture purposes and the establishment of site-specific pathogen histories for each animal population. Shellfish pathogen histories are established by histological examinations of at least 30 individual adults and/or juveniles from each natal site or farmed area considered to be a distinct population with potentially different site-specific pathogen histories as determined by planktonic drift zones (Meyers 2003). These zones are broad geographic areas defined by larval drift patterns determined through dispersal by tides and ocean currents (RaLonde 1993) that most likely affect pathogen distri- bution as well. Consequently, partial ADFG oversight for the mariculture industry is administered through the policy. During the 1980s and early 1990s, most shellfish transports within state waters were imported juvenile Pacific oysters Crassostrea gigas. In later years, the establishment of a shellfish hatchery for the industry and new mariculture legislation generated additional interest in farming indigenous species of clams, mussels and scallops.

As a result of several years of diagnostic examinations, ADFG fish pathologists identified a variety of infectious agents and parasites from farmed and wild bivalve molluscs (Meyers \& Burton 2009), including 2 viruses isolated by fish cell culture and 2 other types of virus-like particles associated with histological intranuclear inclusion bodies. The present study summarizes these results from 1987 to 2009 and provides the first description of poikilothermic viruses from Alaskan waters isolated from or observed within the 
tissues of 4 species of bivalve molluscs: geoduck clam Panope abrupta, native littleneck clam Protothaca staminea, purple-hinged rock scallop Crassadoma gigantea and Pacific oyster Crassostrea gigas.

\section{MATERIALS AND METHODS}

\section{Histology and transmission electron microscopy} (TEM). Standard histological procedures were performed on all bivalve samples submitted for examination. Whole juvenile animals, cross-sections of adult animals and selected tissues from the larger scallops and clams were preserved in Helley's or Bouin's fixatives and embedded in paraffin for sectioning and staining with hematoxylin and eosin (H\&E). Those tissues routinely selected and cross-sectioning methods used during necropsy are described in detail elsewhere (Short \& Meyers 2000).

TEM was performed on preserved inoculated fish cell cultures showing cytopathic effect (CPE) and on targeted cytopathology from stained histological sections following protocols previously described in Meyers (2000). Despite the reduced ultrastructural detail of host cell and virus particle morphologies in deparaffinized tissues, use of these tissues for TEM is the best alternative for locating targeted cell pathologies when the areas of interest are few and unlikely to be found by random examination of freshly fixed tissues.

Cultured fish cells showing CPE were scraped from affected wells, pelleted at $3200 \times g$ and preserved overnight at $4^{\circ} \mathrm{C}$ in $0.1 \mathrm{M}$ cacodylate-buffered ( $\mathrm{pH} 7.8$ ) 2 to $4 \%$ glutaraldehyde. Preserved materials were post-fixed in cacodylate-buffered $1 \%$ osmium tetroxide for 1 to $2 \mathrm{~h}$ at room temperature, dehydrated through a series of ethanol solutions and embedded in Spurr's resin. Ultrathin sections were mounted on slotted $75 \times 300$ mesh copper grids and stained in $4 \%$ aqueous uranyl acetate and $2.6 \%$ lead citrate. Grids were examined with a Philips EM 300 at 60 to $80 \mathrm{kV}$.

Areas of cytopathology in histologically stained sections were marked by etching on the underside of the slide. Slides were submerged in xylene to remove coverslips and paraffin from the sections. Sections were post-fixed 1 to $2 \mathrm{~h}$ in xylene containing $1 \%$ osmium tetroxide then flooded with a 1:1 mixture of Spurr's resin and $100 \%$ ethanol for $1 \mathrm{~h}$ that was replaced with complete resin for $1 \mathrm{~h}$ of additional infiltration. The complete resin was replaced with fresh resin and the slide was cured in a $70^{\circ} \mathrm{C}$ oven overnight. The cured resin containing the etched area of targeted section was dissected and gradually teased from the slide surface with a narrow scalpel blade while flooding distilled water between the resin and glass slide. The excised chip of embedded section was placed, section- side down, in a resin-filled capsule that was cured overnight followed by thin sectioning, staining and ultrastructural examination (Meyers 2000).

Negative staining of isolated virus used standard methods (Meyers 2000) that, briefly, included: pelleting the virus from cell culture supernatant at $81000 \times g$ for $3 \mathrm{~h}$; resuspension of the pellet in 0.5 to $1.0 \mathrm{ml}$ distilled water; mixing $0.02 \mathrm{ml}$ of the virus suspension with an equal volume of $2 \%(\mathrm{w} / \mathrm{v})$ phosphotungstic acid on a glass slide; touching formvar-coated copper grids to the virus/stain mixture; and air-drying the resultant film for later examination by TEM.

Virology and cell culture. Monolayers of bluegill Lepomis macrochirus fry cells (BF-2) (Wolf et al. 1966) were grown in 24-well plates for inoculation of virus samples. Methods (Follett et al. 2000) included the following details. Cells were grown in Eagle's minimum essential medium (MEM) with: a $\mathrm{pH}$ of $7.4 ; 10 \%$ final concentration fetal bovine serum (FBS; thus MEM-10); $0.3 \%$ tryptose phosphate; $50 \mathrm{ug} \mathrm{ml}^{-1}$ gentamicin $(1 \times)$; $2.5 \mu \mathrm{g} \mathrm{ml}^{-1}$ amphotericin-B (1×); $0.04 \mathrm{mM}$ L-glutamine; and $5.4 \mathrm{mM}$ sodium bicarbonate with or without $15 \mathrm{mM}$ tris buffer. Cells formed monolayers at $23^{\circ} \mathrm{C}$ and were incubated at $15^{\circ} \mathrm{C}$ after inoculation and during $1 \mathrm{~h}$ adsorption with test samples. In some instances, cell monolayers were pre-treated for 30 to $60 \mathrm{~min}$ with $7 \%$ polyethylene glycol (PEG) to increase potential virus sensitivity of the cells (Batts \& Winton 1989). After brief refrigeration $\left(4^{\circ} \mathrm{C}\right)$, test samples of pooled digestive gland and mantle tissues from 2 to 5 bivalves were homogenized and diluted 1:10 (w/v) in MEM-10 followed by centrifugation at 3200 to $6000 \times g$ at $4{ }^{\circ} \mathrm{C}$ for $20 \mathrm{~min}$. Replicate cell monolayers were inoculated with supernatant volumes of $0.1 \mathrm{ml}$ using 2 dilutions $\left(10^{-2}\right.$ and $\left.10^{-3}\right)$ with a fluid overlay of MEM-10 containing either $1 \times$ or $3 \times$ of antibiotic and fungistat. Occasionally, supernatants from samples were incubated overnight in a cocktail of antibiotic and fungistat to reduce potential contamination (Follett et al. 2000). Primary and blind passages of inoculated samples were monitored for 15 to $21 \mathrm{~d}$. Sometimes a third $14 \mathrm{~d}$ passage was done with cell cultures having suspected CPE. The minimum levels of detection were 50 to 100 infectious particles $\mathrm{g} \mathrm{m}^{-1}$ of pooled tissue homogenate.

A very small number of adult bivalve cases submitted were tested with BF-2 cell cultures. This testing examined for the presence of potential fish viruses of transport significance which may become concentrated within mollusc tissues from ambient seawater through filter feeding (Meyers 1984). The BF-2 cell line was selected because it supports the replication of several known fish viruses and is relatively tolerant of the occasional cytotoxicity from homogenized bivalve tissues. Virus testing by fish cell culture was not done for any juvenile bivalve species. 
Preliminary biochemical characterization of virus isolates was performed with $\mathrm{TCID}_{50}$ endpoint dilutions (Reed \& Muench 1938) using standard tests for $\mathrm{pH}$ stability, chloroform sensitivity and replication in the presence of a DNA inhibitor (5-iodo-2-deoxyuridine, IUdR) compared to control titrations of untreated virus (Meyers 1979).

\section{RESULTS}

The life stages, species and numbers of bivalve molluscs submitted for diagnostic examination from 1987 to 2009 from sites in south-central and southeast Alaska are listed in Table 1 with general locations shown in Fig. 1. Frequencies of virus isolation and histological observations of intranuclear inclusion bodies from examined bivalve tissues are listed in Table 2. In general, all bivalves examined were from apparently healthy populations. Pacific oysters are not native to Alaska and must be imported from health-certified sources in the Pacific Northwest. Oysters are imported as larvae and spat not exceeding $20 \mathrm{~mm}$ in diameter for grow-out or staging and distribution to other farm sites. However, some of these oysters were maintained for brood stock and spawning at a shellfish hatchery in Seward (Fig. 1), where a small percentage of their progeny were included in our juvenile histological oyster data. Except for the brood stocks at the Seward hatchery, most imported oysters are sold for consump-

Table 1. Panope abrupta, Protothaca staminea, Crassadoma gigantea and Crassostrea gigas. Life stage, species and numbers of bivalve molluscs sampled from 1987 through 2009 from sites in south-central and southeast Alaska, USA, with general locations shown in Fig. 1. A: adult; J: juvenile; W: west of main heading; SW: southwest of main heading; SE: southeast of main heading

\begin{tabular}{|c|c|c|c|c|c|c|c|c|}
\hline \multirow[t]{2}{*}{ Location } & \multicolumn{2}{|c|}{ Geoduck clam } & \multicolumn{2}{|c|}{ Littleneck clam } & \multicolumn{2}{|c|}{ Rock scallop } & \multicolumn{2}{|c|}{ Pacific oyster } \\
\hline & A & $\mathrm{J}$ & A & $\mathrm{J}$ & $\mathrm{A}$ & $\mathrm{J}$ & $\mathrm{A}$ & $\mathrm{J}$ \\
\hline Annette Island (Metlakatla) & & & 59 & & 32 & & & \\
\hline Blashke Islands & & & 50 & & & & 30 & \\
\hline Lava Bay & & & & & & & & 28 \\
\hline Elfin Cove & & & & & 32 & & 121 & \\
\hline \multicolumn{9}{|l|}{ Etolin Island } \\
\hline Canoe Lagoon & & & & & & & 54 & \\
\hline Mosman Island (W) & & & & & & & 36 & \\
\hline Zimovia Strait & & & & & & & 31 & \\
\hline Gravina Island (Vallenar Bay) & 40 & & & & & & & \\
\hline Homer (Anchor Point) & & & & & & & 30 & \\
\hline Horseshoe Island (Stedman Cove) & & & & 59 & 37 & & & 110 \\
\hline Kachemak Bay & & & 35 & & & & & \\
\hline Jackolof Bay & & & & & 32 & & & 33 \\
\hline Halibut Cove & & & & & & & & 622 \\
\hline Ketchikan (Saxman) & & & 52 & & & & & \\
\hline Kodiak & & & & & & 63 & & 29 \\
\hline Noyes Island (Big Steamboat Bay) & 33 & & & & & & & \\
\hline Petersburg & & & & & & & 35 & \\
\hline Port Graham (Nanwalek) & & & 30 & & & & & \\
\hline \multicolumn{9}{|l|}{ Prince William Sound } \\
\hline Chenega Bay & & & & & & & 31 & 62 \\
\hline Cordova & & & & & & & & 73 \\
\hline Deep Bay & & & & & & & 29 & \\
\hline Eaglek Bay & & & & & & & 29 & \\
\hline Fairmont Island & & & & & & & 26 & \\
\hline Main Bay & & & & & & & & 68 \\
\hline Naked Island & & & 34 & & & & & \\
\hline Tatitlek & & & 31 & & & & & \\
\hline Seward hatchery & & 1021 & & 970 & & 126 & & 696 \\
\hline Seward (Resurrection Bay) & & & & & & & 95 & 63 \\
\hline Sitka Sound & & & & & 30 & 13 & & \\
\hline Tenass Passage (Kosciusko Island) & & & 40 & & 32 & & 30 & 48 \\
\hline Naukati Bay (SE) & & & & & & & & 343 \\
\hline Sea Otter Sound (SW) & & & 35 & & & & 32 & \\
\hline Tokeen Bay & & & & & & & 32 & \\
\hline Yakutat & & & & & & & 90 & \\
\hline Totals & 73 & 1021 & 366 & 1029 & 195 & 202 & 731 & 2175 \\
\hline
\end{tabular}




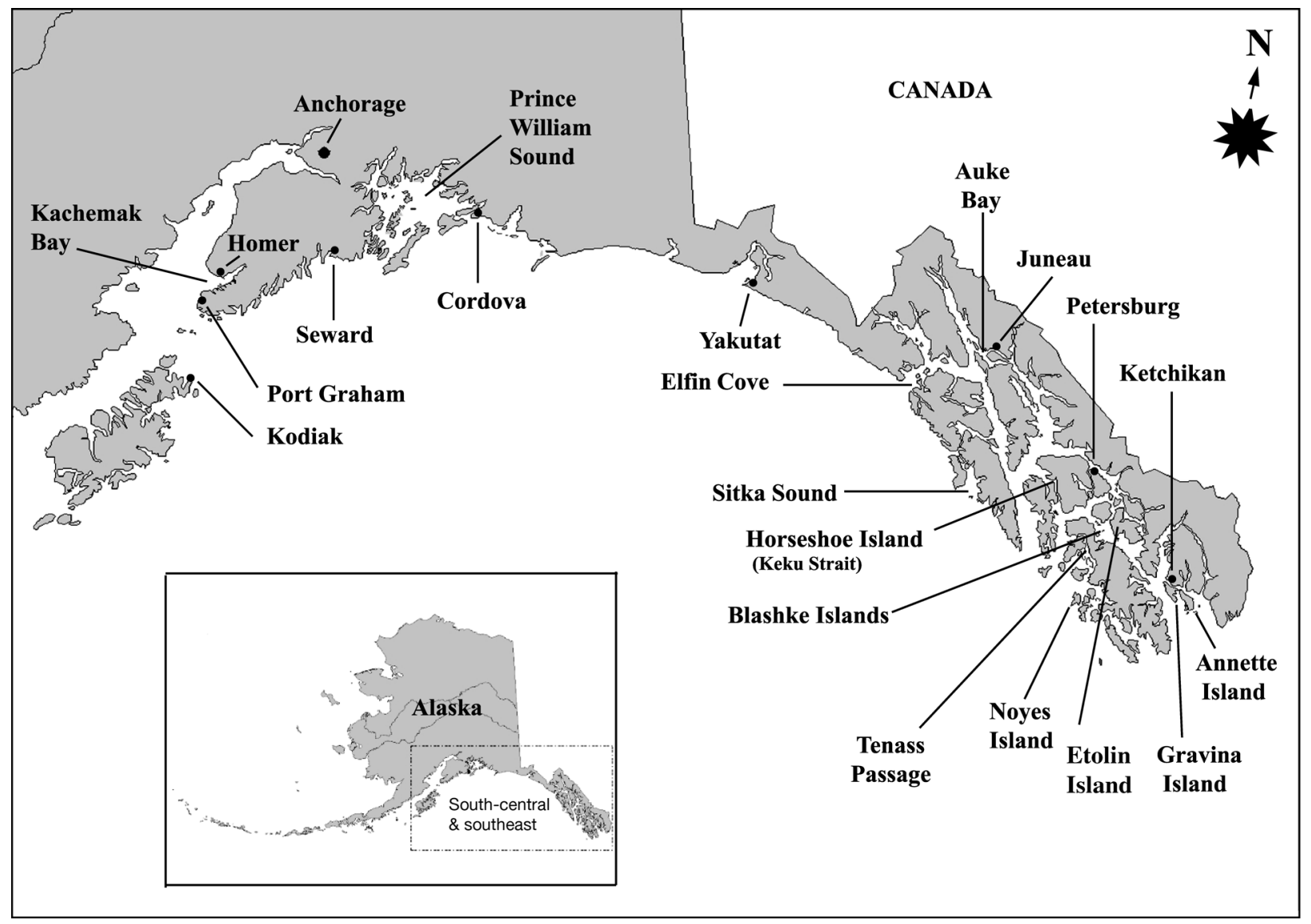

Fig. 1. General locations of sample sites for oyster, clam and scallop collections in south-central and southeast Alaska from 1987 through 2009

tion when reaching market size. Therefore, there are fewer adult oysters than juveniles represented in the data. Also, the extensive geographic sizes of the larval drift zones have potentially broadened the distribution of distinct pathogen histories which has limited the need for extensive or more frequent diagnostic sampling. All other examined juvenile bivalve species were from wild spat that settled naturally on farm gear or were spawned from captive brood stocks indigenous to Alaska maintained at the Seward hatchery. Because the interest in farming scallops and clams has been relatively recent, considerably fewer samples of these species were represented in the overall data.

\section{Geoduck clam Panope abrupta (received from 1997 to 2009)}

Pooled samples from 30 adult wild geoduck clams collected as brood-stock in July 1997 from Vallenar Bay on the north end of Gravina Island in southeast Alaska (Fig. 1) were test-negative on primary passage in BF-2 cells after $15 \mathrm{~d}$. Subsequent blind passage pro- duced CPE in one pooled sample after $7 \mathrm{~d}$ and limited CPE in the remaining 5 pooled samples by $21 \mathrm{~d}$ (Table 2). Extensive CPE consisting of large syncytial cell plaques that destroyed the cell monolayers in 7 to $10 \mathrm{~d}$ was produced by all samples beginning at $4 \mathrm{~d}$ of a third passage. At least 3 additional fish cell lines supported similar CPE when inoculated with filtered $(0.45 \mu \mathrm{m})$ supernatant from infected cell cultures. Despite blind passages, 2 additional pooled samples from 10 clams collected at the same site later in November were test-negative for viral CPE as were pooled samples from 33 clams (Table 2) collected in May of the same year from Big Steamboat Bay on Noyes Island (Fig. 1). The virus isolate from the July samples was resistant to acid $\mathrm{pH}(3.0)$, resistant to chloroform and replicated in the presence of IUdR, suggesting a nonenveloped, cytoplasmic RNA virus. Ultrastructural examination of infected BF-2 cells showed arrays of cytoplasmic virus particles (Fig. 2A) 63 to $68 \mathrm{~nm}$ in diameter with double capsid morphology by negative staining (Fig. 2B). These preliminary physical and morphological characteristics with syncytial-type CPE were typical of an Aquareovirus that produced no 

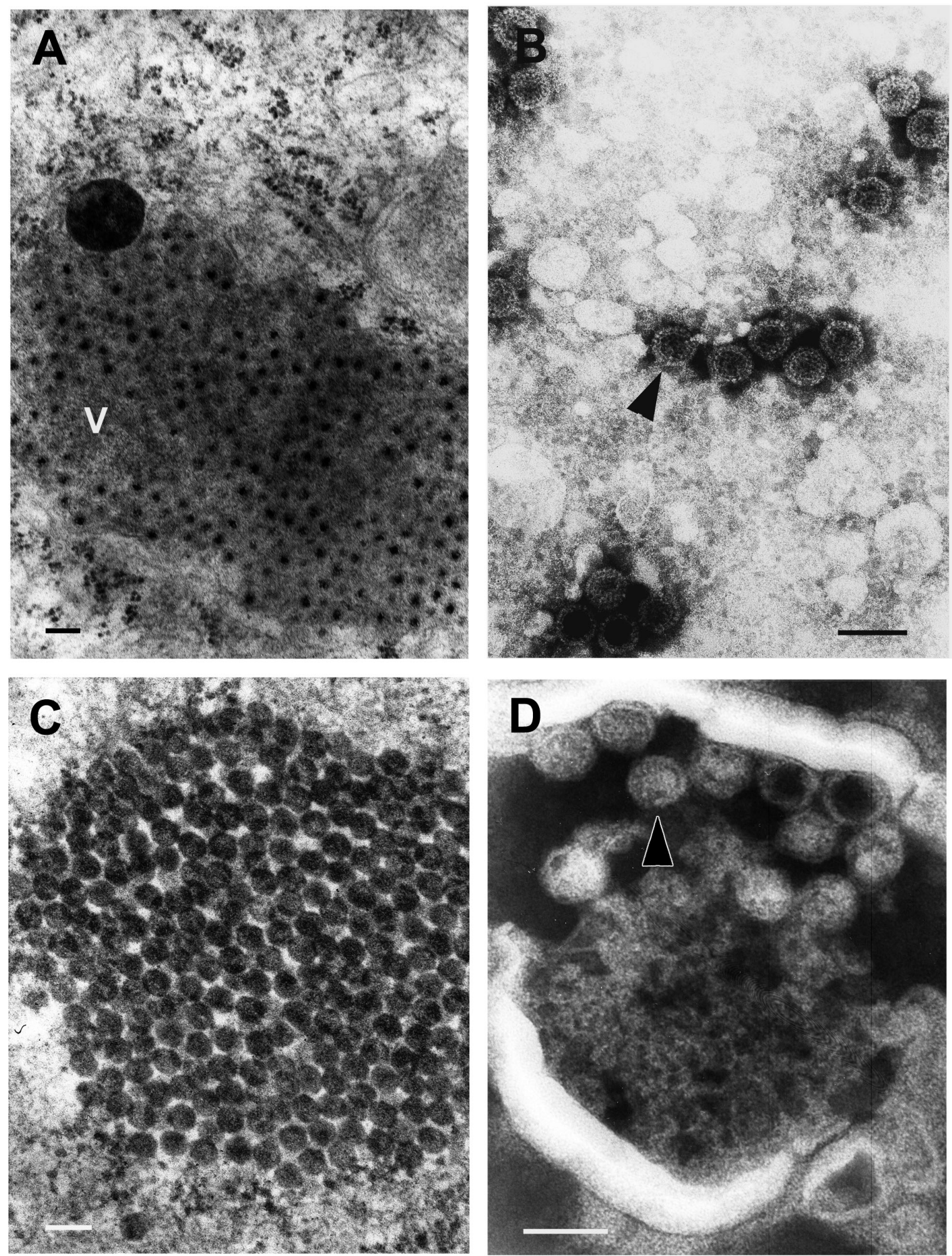

Fig. 2. Panope abrupta and Protothaca staminea. Transmission electron microscopy of aquareovirus and aquabirna-like virus in inoculated bluegill fry (BF-2) cells and in negative stains. (A) BF-2 cell with cytoplasmic arrays of aquareovirus particles (v) from Panope abrupta; (B) negative stain of particles (arrowhead) in (A) showing typical double capsid morphology; (C) BF-2 cell with cytoplasmic aggregate of hexagonal-shaped aquabirna-like virus particles from Protothaca staminea; (D) negative stain of virus particles (arrowhead) in (C). Scale bars $=100 \mathrm{~nm}$ 

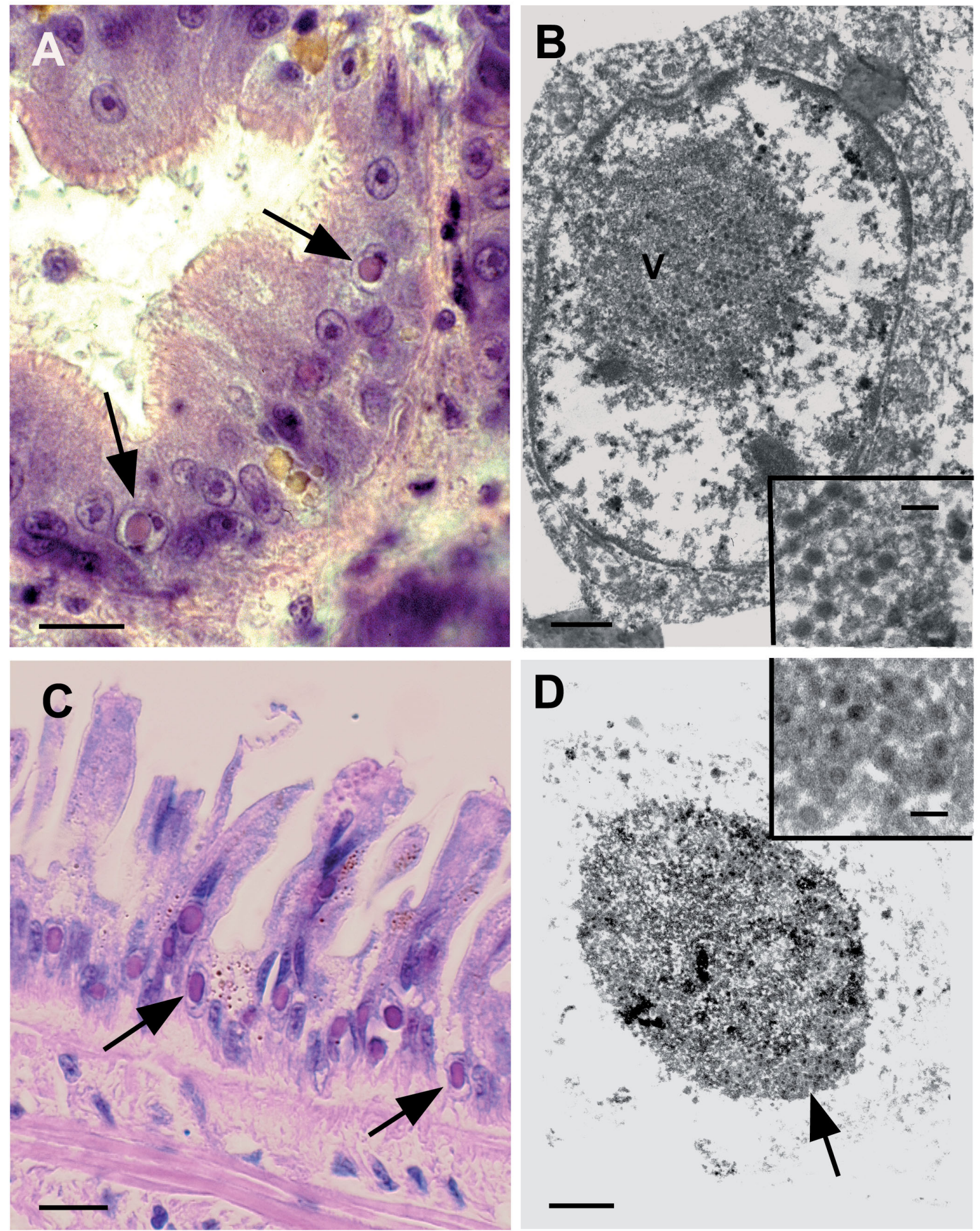

Fig. 3. Protothaca staminea and Crassadoma gigantea. Histological sections and transmission electron microscopy (TEM) of Cowdry Type-A intranuclear inclusions in P. staminea and C. gigantea. (A) Cowdry Type A inclusions (arrows) in the nuclei of digestive tubule epithelium of $P$. staminea. H\&E staining; scale bar $=10 \mu \mathrm{m}$. (B) TEM of similar nuclear inclusion body containing arrays of virus-like particles $(\mathrm{v})$; scale bar $=500 \mathrm{~nm}$. Inset: higher magnification of same particles; scale bar $=100 \mathrm{~nm}$; $(\mathrm{C})$ Cowdry Type A inclusions (arrows) in the nuclei of mantle epithelium of C. gigantea. H\&E staining; scale bar $=10 \mu \mathrm{m}$. (D) TEM of similar inclusion body with virus-like particles at the periphery (arrow); scale bar $=500 \mathrm{~nm}$. Inset: higher magnification of same particles; 
mately 67 to $75 \mathrm{~nm}$ in diameter appeared similar in morphology but slightly smaller than the virus-like particles observed in Cowdry Type A inclusions described in the present study from the native littleneck clam. Adult and juvenile scallops from other sites shown in Table 1 and Fig. 1 were test-negative for these inclusion bodies and other types of known virusassociated cytopathology (Table 2). Adults from 3 sites (Sitka Sound, Annette Island, Elfin Cove; Fig. 1) were also test-negative on fish cell culture.

\section{Pacific oyster Crassostrea gigas (examined from 1987 to 2009)}

Herpesvirus-like agent

Two juvenile Pacific oysters among 39 collected May 2006 (Table 2) from a south-central shellfish farm in Prince William Sound near Cordova (Fig. 1) had one to several Cowdry Type A intranuclear inclusion bodies in the mantle epithelium (Fig. 4), typical of reported herpesvirus infections in oysters (Farley et al. 1972).
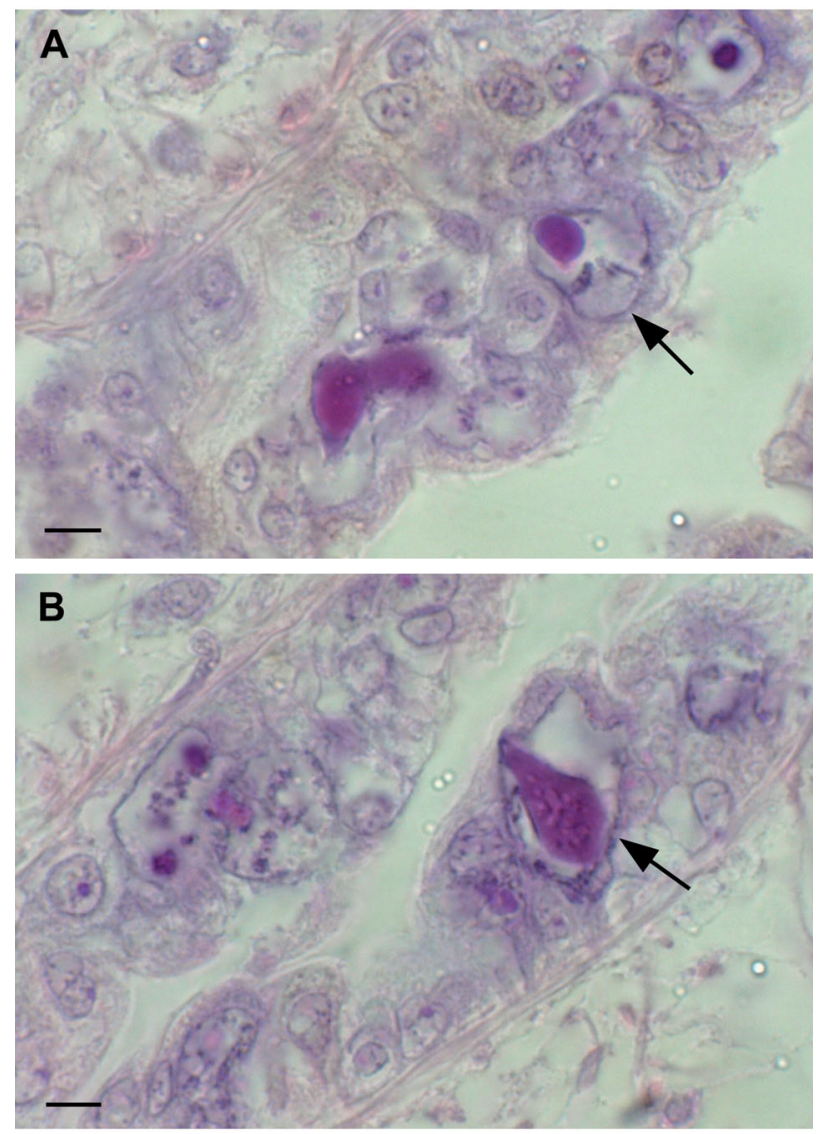

Fig. 4. Crassostrea gigas. Mantle epithelium of C. gigas with 2 examples $(A, B)$ of Cowdry Type $A$ intranuclear inclusion bodies (arrows). H\&E staining; scale bars $=5 \mu \mathrm{m}$
However, inclusion bodies were few and too widely dispersed within histological sections to attempt confirmation of virus by TEM. Ten pools of 6 juvenile oysters collected from the same site in early June 2006 and similar aged juveniles from the original certified shellfish supplier in Washington were negative by PCR for the oyster herpesvirus OsHV-1 (R. Elston unpubl. data). Cowdry Type A inclusion bodies were not observed in other juvenile and adult oysters examined (Table 2) from additional farm sites listed in Table 1.

\section{Papilloma- or polyoma-like virus}

Adult 18 mo old Pacific oysters collected from Yakutat (Fig. 1) in November 1990 were being held in recirculating seawater tanks at the National Marine Fisheries Service laboratory in Auke Bay near Juneau when 30 animals were submitted for laboratory examination. Hypertrophied gametocytes (1 to 13 per section) containing large intranuclear basophilic inclusion bodies (Figs. 5A,B) were observed in histological sections from 3 male and 3 female oysters. Ultrastructural examination of inclusion body material from one affected male showed arrays of intranuclear icosahedral virus-like particles (Fig. 5C) 38 to $40 \mathrm{~nm}$ in diameter, consistent with a virus previously described as causing hypertrophied gametocytes (ovacystis) in eastern Crassostrea virginica (Farley 1976, Winstead \& Courtney 2003) and Pacific (Choi et al. 2004, Garcia et al. 2006) oysters. The same inclusion bodies or other known types of virus-associated cytopathology were not observed (Table 2) in any of the juvenile or adult oysters examined from the other farm sites listed in Table 1. The few adult oysters examined for virus by fish cell culture were also test-negative (Table 2).

\section{DISCUSSION}

Our isolation of 2 different viruses from fish cell cultures inoculated with 2 species of clam tissues most likely represented bioaccumulation of the viruses from some other source. This explanation is plausible because the bivalve filter-feeding mechanism is efficient at concentrating various viruses from polluted waters that are indicators of sewage contamination (Speirs et al. 1987, Ahmed 1991). Likewise, bivalve molluscs do bioaccumulate fish viruses including aquareoviruses (Meyers 1979, 1980, 1984) and aquabirnaviruses (Hill \& Alderman 1977, Mortensen 1993, Rivas et al. 1993). The established genogroup A identity of our aquareovirus further supports a fish host as the source. Although there are reports of aquabirnaviruses specifically infecting bivalve molluscs, these 

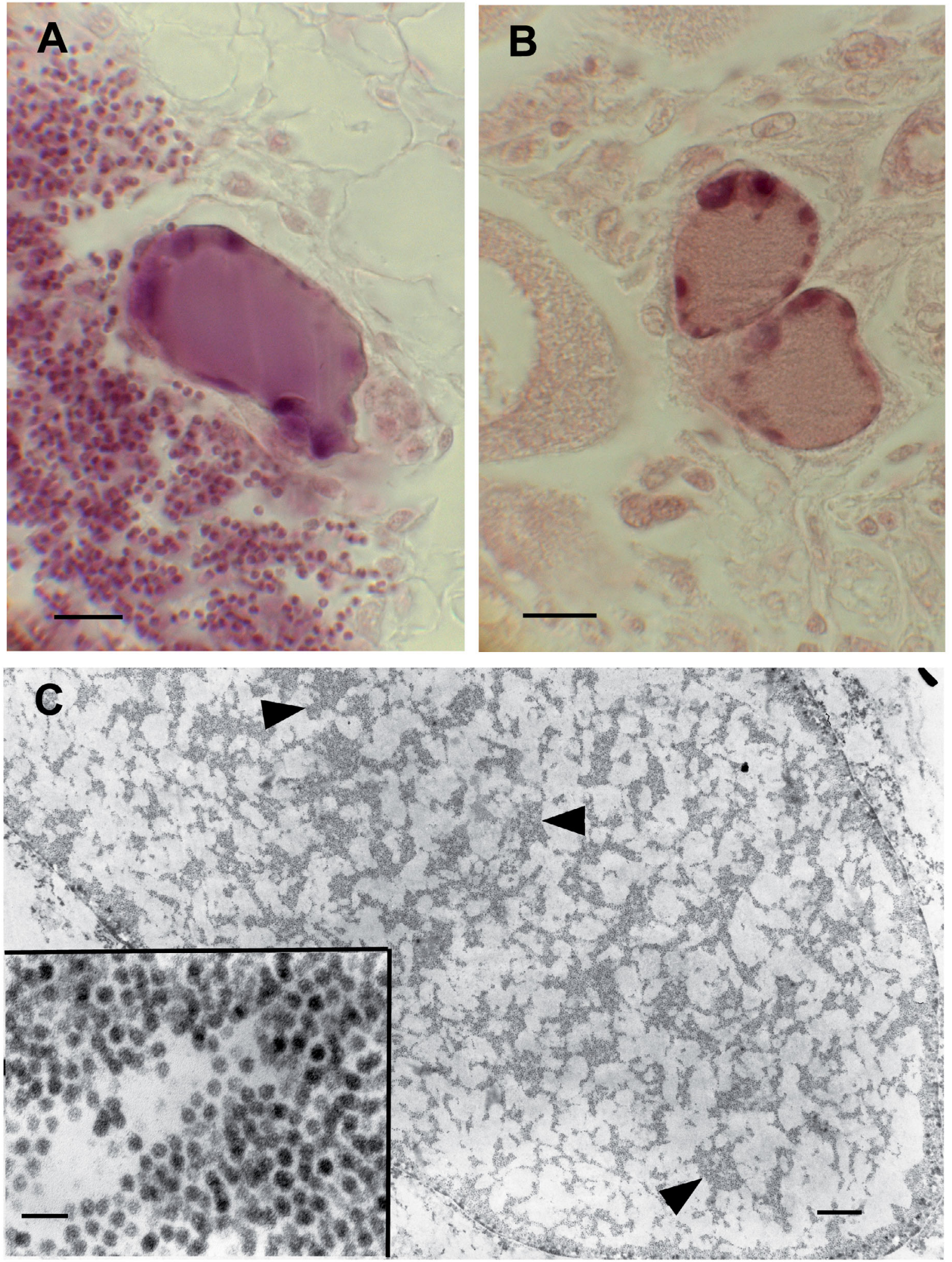

Fig. 5. Crassostrea gigas. Histological sections and transmission electron microscopy (TEM) of gametogenic hypertrophy in C. gigas. Enlarged gametocytes in (A) male and (B) female oysters. H\&E staining; scale bars $=10 \mu$ m. (C) TEM of male gametocyte with hypertrophied nucleus containing arrays of virus-like particles (arrowheads); scale bar $=1 \mu \mathrm{m}$. Inset: higher magnification of same particles; scale bar $=100 \mathrm{~nm}$ 
viruses, unlike our aquabirna-like virus isolate, have generally been associated with some degree of cell pathology and/or mortality, often in stressed bivalve hosts (Lo et al. 1988, Chou et al. 1994, Suzuki \& Nojima 1999, Kitamura et al. 2002, Maeno et al. 2006).

Aquareoviruses, with few exceptions (Meyers 1980, Goodwin et al. 2006), are relatively apathogenic for most fish species including salmonids (Hetrick \& Hedrick 1993). In Alaska, apathogenic aquareoviruses have also been isolated from adult chinook salmon Oncorhynchus tshawytscha when tested for other viruses (Meyers et al. 2007). In contrast, some aquabirnaviruses isolated from bivalve molluscs are pathogenic for juvenile rainbow trout Oncorhynchus mykiss (Hill 1982) and indistinguishable from reference strains of infectious pancreatic necrosis virus. Consequently, inadvertent transport of our aquabirna-like virus isolate via native littleneck clams was a potential fish health concern that was subsequently mitigated by results of a bioassay study with rainbow trout. This virus isolate caused no significant mortality in rainbow trout fry when exposed to high virus titers by intraperitoneal injection or by immersion, and the virus could not be recovered from virus-exposed fish (ADFG unpubl. data).

A herpesvirus associated with Cowdry Type A intranuclear inclusion bodies was first reported in bivalve molluscs by Farley et al. (1972) in eastern oysters Crassostrea virginica from the Marsh River, Maine, USA. Subsequently, herpes and herpes-like viruses have been reported worldwide in several bivalve species including the Pacific oyster C. gigas in New Zealand (Hine et al. 1992) and Mexico (Vasquez-Yeomans et al. 2004), the European oyster Ostrea edulis (Nicolas et al. 1992), the Antipodean flat oyster in Australia O. angasi (Hine \& Thorne 1997), the Chilean oyster Tiostrea chilensis (Hine et al. 1998), the Manila clam Ruditapes philippinarum (Renault et al. 2001) and carpet shell clam R. decussatus in France (Renault \& Arzul 2001), the Portuguese oyster C. angulata and Suminoe oyster C. rivularis (Arzul et al. 2001a) and the French scallop Pecten maximus (Arzul et al. 2001b). These viruses appear to be most pathogenic for hatchery-reared bivalve larvae and juvenile animals (Hine et al. 1992, Nicolas et al. 1992, Comps \& Cochennec 1993, Renault et al. 1994, Renault \& Arzul 2001, Friedman et al. 2005), while significant mortality in nature may require an environmental stressor such as high seawater temperatures (Burge et al. 2006). Infected adult bivalves are apparently less susceptible to systemic disease (Arzul et al. 2002, Renault \& Novoa 2004), but mortality has occurred when also stressed by high water temperatures (Farley et al. 1972). These reports are consistent with the absence of overt disease regarding the herpes-like virus-associated inclusion bodies observed in Alaskan sub-adult and adult rock scallops and native littleneck clams. Interestingly, no such inclusion bodies nor suspicious mortality have been observed in progeny bivalves produced at the Seward hatchery by these same broodstocks from which vertical transmission of a herpesvirus might be expected (Arzul et al. 2002). This observation suggests that Alaskan herpes-like viruses may be less pathogenic in natural bivalve populations or within the hatchery environment, possibly due to the consistently colder seawater temperatures in Alaska. Seawater temperatures rarely reach $20^{\circ} \mathrm{C}$ in surface waters, which is much lower than the 25 to $26^{\circ} \mathrm{C}$ generally associated with productive infections and epizootics caused by OsHV-1 (Le Deuff et al. 1996). Although similar inclusion bodies observed in the juvenile Alaskan Pacific oysters also were not associated with apparent disease or mortality, their viral etiology remains unconfirmed. Oysters from the same site and the original supplier were negative by PCR for OsHV-1, suggesting the inclusions were not caused by virus, or the virus was not present in the samples tested; alternatively, if present, the viral genome may not have been recognized by the OsHV-1 primers. As an example of the latter, one report investigating mortality of herpesvirus-infected juvenile oysters in Tomales Bay, California, USA, found no Cowdry Type A inclusions despite the fact that oysters were PCR-positive for an oyster herpesvirus very similar but not identical to OsHV-1 (Friedman et al. 2005).

In contrast to herpesviruses in vertebrate hosts, herpesviruses in bivalve molluscs may be less hostspecific as reported for OsHV-1 in Pacific oysters (Arzul et al. 2001a,b,c). Traditional methods of observed cytopathology with ultrastructural confirmation of associated virus (Hine \& Thorne 1997, Renault et al. 2000) suggest that an additional clam and scallop species may be hosts for herpes-like viruses in Alaska. In native littleneck clams, the virus appears to be ubiquitous based on the presence of typical intranuclear inclusion bodies in all populations examined. Further investigation will be necessary to determine whether these viruses are the same as or different than OsHV-1. Clearly, the presence of potentially pathogenic herpesviruses in native bivalve mollusc reservoirs emphasizes a future disease risk for Alaskan mariculture, especially in the event of rising seawater temperatures due to global warming. Avoiding complete monoculture by maintaining species diversity as well as genetic diversity has been recommended in Europe to minimize a similar disease risk in commercial bivalve mariculture (http://wwz.ifremer.fr/index. php/aquaculture_en/filieres/filiere_mollusques).

The term ovacystis denotes massive hypertrophy of both male and female gametocytes caused by an associated papilloma- or polyoma-like virus referred to in previous literature as papovavirus. The condition was 
first described in ova of Crassostrea virginica from the Piscataqua River, Maine, USA (Farley 1976, 1978). Papovavirus, causing gametogenic or other cellular hypertrophy, has subsequently been reported in C. virginica from the Gulf of Mexico (Winstead \& Courtney 2003) and Atlantic Canada (McGladdery \& Stephenson 1994), in C. gigas from Korea (Choi et al. 2004), France (Garcia et al. 2006), Germany (Watermann et al. 2008) and Ireland (Cheslett et al. 2009), in the golden-lipped pearl oyster Pinctada maxima from Torres Strait, Australia (Norton et al. 1993), in the softshell clam Mya arenaria in Massachusetts, USA, and Ruditapes philippinarum from Spain (Elston 1997, Montes et al. 2001). Similar examples of unconfirmed virus-associated gametogenic hypertrophy have been reported in other ostreid species including Saccostrea glomerata, C. rhizophorae, Ostrea edulis and Ostreola conchaphila (Farley 1978, Bower et al. 1994). Despite purported oncogenic potential, viral gametogenic hypertrophy appears to have very little pathological significance in affected C. virginica (Meyers 1981), which also appears to be true for $C$. gigas reared in Alaskan waters.

In summary, this is the first description of poikilothermic viruses isolated from or observed in the tissues of wild and farmed bivalve molluscs in Alaska. The aquareovirus and aquabirna-like virus isolated from geoduck and native littleneck clams as well as the observed herpes-like viruses in native littleneck clams and rock scallops appear to be indigenous to Alaska. Alternatively, because Pacific oysters have been imported, it is possible that the virus causing gametogenic hypertrophy and the unconfirmed herpes-like virus inclusions observed in farmed oysters may have originated from the parent brood-stocks outside Alaskan waters. Except for the herpes-like virus in native littleneck clams, the prevalences of these viruses and virus-like conditions appear low, most likely because their occurrences have been underestimated by the small numbers of animals examined and by the low sensitivity of histological detection.

Acknowledgements. This work was funded through the Commercial Fisheries and Sport Fish Divisions of the Alaska Department of Fish and Game.

\section{LITERATURE CITED}

Ahmed FE (ed) (1991) Seafood safety. National Academy Press, Washington, DC

Arzul I, Renault T, Lipart C (2001a) Experimental herpes-like viral infections in marine bivalves: demonstration of interspecies transmission. Dis Aquat Org 46:1-6

> Arzul I, Nicolas JL, Davison AJ, Renault T (2001b) French scallops: a new host for ostreid herpesvirus-1. Virology 290:342-349
Arzul I, Renault T, Lipart C, Davison AJ (2001c) Evidence for interspecies transmission of oyster herpesvirus in marine bivalves. J Gen Virol 82:865-870

Arzul I, Renault T, Thebault A, Gerard G (2002) Detection of oyster herpesvirus DNA and proteins in asymptomatic Crassostrea gigas adults. Virus Res 84:151-160

> Batts WN, Winton JR (1989) Enhanced detection of infectious hematopoietic necrosis virus and other fish viruses by pretreatment of cell monolayers with polyethylene glycol. J Aquat Anim Health 1:284-290

> Bower SM, McGladdery SE, Price IM (1994) Synopsis of infectious diseases and parasites of commercially exploited shellfish. Annu Rev Fish Dis 4:1-199

> Burge CA, Griffin FJ, Friedman CS (2006) Mortality and herpesvirus infections of the Pacific oyster Crassostrea gigas in Tomales Bay, California, USA. Dis Aquat Org 72:31-43

Cheslett D, McKiernan F, Hickey C, Collins E (2009) Viral gametocytic hypertrophy of the Pacific oyster Crassostrea gigas in Ireland. Dis Aquat Org 83:181-185

> Choi DL, Lee NS, Choi HJ, Park MA, McGladdery SE, Park MS (2004) Viral gametogenic hypertrophy caused by a papova-like virus infection in the Pacific oyster Crassostrea gigas in Korea. Dis Aquat Org 59:205-209

Chou HY, Li HJ, Lo CF (1994) Pathogenicity of a birnavirus to hard clam (Meretrix lusoria) and effect of temperature stress on its virulence. Fish Pathol 29:171-175

Comps M, Cochennec N (1993) A herpes-like virus from the European oyster Ostrea edulis L. J Invertebr Pathol 62: 201-203

Elston R (1997) Special topic review: bivalve mollusc viruses. World J Microbiol Biotechnol 13:393-403

> Farley CA (1976) Ultrastructural observations on epizootic neoplasia and lytic virus infection in bivalve mollusks. Prog Exp Tumor Res 20:283-294

Farley CA (1978) Viruses and virus-like lesions in marine mollusks. Mar Fish Rev 40:18-20

- Farley CA, Banfield WG, Kasnic G Jr, Foster WS (1972) Oyster herpes-type virus. Science 178:759-760

> Fijan N, Sulimanovic D, Bearzotti M, Muzinic D and others (1983) Some properties of the Epithelioma papulosum cyprini (EPC) cell line from carp Cyprinus carpio. Ann Inst Pasteur Virol 134:207-220

Follett J, Thomas J, Fried M, Short S, Burton T, Meyers TR (2000) Virology and cell culture. In: Meyers TR (ed) Fish pathology section laboratory manual, 2nd edn. Commercial Fisheries Division, Alaska Department of Fish and Game, Juneau, p 5-1 to 5-45

> Friedman CS, Estes RM, Stokes NA, Burge CA and others (2005) Herpes virus in juvenile Pacific oysters Crassostrea gigas from Tomales Bay, California, coincides with summer mortality episodes. Dis Aquat Org 63:33-41

> Garcia C, Robert M, Arzul I, Chollet B and others (2006) Viral gametocytic hypertrophy of Crassostrea gigas in France: from occasional records to disease emergence? Dis Aquat Org 70:193-199

> Goodwin AE, Nayak DK, Bakal RS (2006) Natural infections of wild creek chubs and cultured fathead minnow by Chinese grass carp reovirus (golden shiner virus). J Aquat Anim Health 18:35-38

Hetrick FM, Hedrick RP (1993) New viruses described in finfish from 1988-1992. Annu Rev Fish Dis 3:187-207

Hill BJ (1982) Infectious pancreatic necrosis virus and its virulence. In: Roberts RJ (ed) Microbial diseases of fish. Academic Press, New York, p 91-114

Hill BJ, Alderman DJ (1977) Observations on the experimental infection of Ostrea edulis with two molluscan viruses. Haliotis 8:297-299 
Hine PM, Thorne T (1997) Replication of herpes-like viruses in haemocytes of adult flat oysters Ostrea angasi: an ultrastructural study. Dis Aquat Org 29:189-196

Hine PM, Wesney B, Hay BE (1992) Herpesviruses associated with mortalities among hatchery-reared larval Pacific oysters Crassostrea gigas. Dis Aquat Org 12:135-142

$>$ Hine PM, Wesney B, Besant P (1998) Replication of herpeslike viruses in larvae of the flat oyster Tiostrea chilensis at ambient temperatures. Dis Aquat Org 32:161-171

Kitamura SI, Tomaru Y, Kawabata Z, Suzuki S (2002) Detection of marine birnavirus in the Japanese pearl oyster Pinctada fucata and seawater from different depths. Dis Aquat Org 50:211-217

> Le Deuff R, Renault T, Gérard A (1996) Effects of temperature on herpes-like virus detection among hatchery-reared larval Pacific oysters Crassostrea gigas. Dis Aquat Org 24: 149-157

Lo CF, Hong YW, Huang SY, Wang CH (1988) The characteristics of the virus isolated from the gill of clam, Meretrix lusoria. Fish Pathol 23:147-154

- Maeno Y, Yurimoto T, Nasu H, Ito S and others (2006) Viruslike particles associated with mass mortalities of the pen shell Atrina pectinata in Japan. Dis Aquat Org 71:169-173

McGladdery SE, Stephenson MF (1994) A viral infection of the gonads of eastern oyster (Crassostrea virginica) from Atlantic Canada. Bull Aquac Assoc Can 94:84-86

Meyers TR (1979) A reo-like virus isolated from juvenile American oysters (Crassostrea virginica). J Gen Virol 43: 203-212

> Meyers TR (1980) Experimental pathogenicity of reovirus $13 \mathrm{p}_{2}$ for juvenile American oysters Crassostrea virginica (Gmelin) and bluegill fingerlings Lepomis macrochirus (Rafinesque). J Fish Dis 3:187-201

Meyers TR (1981) Endemic diseases of cultured shellfish of Long Island, New York: adult and juvenile American oysters (Crassostrea virginica) and hard clams (Mercenaria mercenaria). Aquaculture 22:305-330

Meyers TR (1984) Marine bivalve mollusks as reservoirs of viral finfish pathogens: significance to marine and anadromous finfish aquaculture. Mar Fish Rev 46:14-17

Meyers TR (2000) Transmission electron microscopy; fixation and sample staining procedures. In: Meyers TR (ed) Fish pathology section laboratory manual, 2nd edn. Commercial Fisheries Division, Alaska Department of Fish and Game, Juneau, AK, p 7-1 to 7-8

Meyers TR (2003) Regulation changes, policies and guidelines for Alaska fish and shellfish health and disease control. Regional Information Report No. 5J03-07, Commercial Fisheries Division, Alaska Department of Fish and Game, Juneau, AK

Meyers TR, Burton T (2009) Diseases of wild and cultured shellfish in Alaska. Commercial Fisheries Division, Alaska Department of Fish and Game, Anchorage, AK

Meyers TR, Burton T, Bentz C, Starkey N (2007) Common diseases of wild and cultured fishes in Alaska. Commercial Fisheries Division, Alaska Department of Fish and Game, Anchorage, AK

Montes JF, Durfort M, Garcia-Valero J (2001) Parasitism by the protozoan Perkinsus atlanticus favours the development of opportunistic infections. Dis Aquat Org 46:57-66

Mortensen SH (1993) Commercially exploited bivalve molluscs in Norway: their health status and potential role as

Editorial responsibility: Eugene Burreson,

Gloucester Point, Virginia, USA vectors of the fish pathogenic infectious pancreatic necrosis virus (IPNV). PhD dissertation, University of Bergen

Nicolas JL, Comps M, Cochennec N (1992) Herpes-like virus infecting Pacific oyster larvae, Crassostrea gigas. Bull Eur Assoc Fish Pathol 12:11-13

> Norton JH, Shepherd MA, Prior HC (1993) Papovavirus-like infection of the golden-lipped pearl oyster, Pinctada maxima, from the Torres Strait, Australia. J Invertebr Pathol 62:198-200

RaLonde R (1993) Shellfish aquaculture in Alaska and the potential of interaction with wild species. Proc 22nd USJapan Aquac Panel Symp, Homer, AK, 21-22 Aug 1993. Alaska Sea Grant Report AK-5G-95-03, Fairbanks, AK, p 27-39

Rangel AAC, Rockemann DD, Hetrick FM, Samal SK (1999) Identification of grass carp hemorrhage virus as a new genogroup of aquareovirus. J Gen Virol 80:2399-2402

Reed LJ, Muench H (1938) A simple method of estimating fifty percent endpoints. Am J Hyg 27:493-497

> Renault T, Arzul I (2001) Herpes-like virus infections in hatchery-reared bivalve larvae in Europe: specific viral DNA detection by PCR. J Fish Dis 24:161-167

> Renault T, Novoa B (2004) Viruses infecting bivalve molluscs. Aquat Living Resour 17:397-409

Renault T, Le Deuff RM, Cochennec N, Maffart P (1994) Herpesviruses associated with mortalities among Pacific oyster, C. gigas, in France-comparative study. Rev Med Vet 145:735-742

> Renault T, Le Deuff RM, Chollet B, Cochennec N, Gérard A (2000) Concomitant herpes-like virus infections in hatchery-reared larvae and nursery-cultured spat Crassostrea gigas and Ostrea edulis. Dis Aquat Org 42:173-183

Renault T, Lipart C, Arzul I (2001) A herpes-like virus infects a non-ostreid bivalve species: virus replication in Ruditapes philippinarum larvae. Dis Aquat Org 45:1-7

Rivas C, Cepeda C, Dopazo CP, Novoa B, Noya M, Barja JL (1993) Marine environment as reservoir of birnaviruses from poikilothermic animals. Aquaculture 115:183-194

Short S, Meyers TR (2000) Histology for finfish and shellfish. In: Meyers TR (ed) Fish pathology section laboratory manual, 2nd edn. Commercial Fisheries Division, Alaska Department of Fish and Game, Juneau, AK, p 6-1 to 6-19

Speirs JI, Pontefract RD, Harwig J (1987) Methods for recovering poliovirus and rotavirus from oysters. Appl Environ Microbiol 53:2666-2670

Suzuki S, Nojima M (1999) Detection of a marine birnavirus in wild molluscan shellfish species from Japan. Fish Pathol 34:121-125

Vasquez-Yeomans R, Caceres-Martinez J, Huerta AF (2004) Herpes-like virus associated with eroded gills of the Pacific oyster Crassostrea gigas in Mexico. J Shellfish Res 23:417-419

> Watermann BT, Herlyn M, Daehne B, Bergmann S, Meemken M, Kolodzey H (2008) Pathology and mass mortality of Pacific oysters, Crassostrea gigas (Thunberg), in 2005 at the East Frisian coast, Germany. J Fish Dis 31:621-630

> Winstead JT, Courtney LA (2003) Ovacystis-like condition in the eastern oyster Crassostrea virginica from the northeastern Gulf of Mexico. Dis Aquat Org 53:89-90

Wolf K, Gravell M, Malsberger RG (1966) Lymphocystis virus: isolation and propagation in centrarchid fish cell lines. Science 151:1004-1005

Submitted: July 30, 2009; Accepted: September 22, 2009 Proofs received from author(s): December 17, 2009 